\title{
EMPLOYEE BENEFITS AS ONE OF FACTORS OF WORK MOTIVATION
}

\author{
Nátalia Stalmašeková ${ }^{1}$, Tatiana Genzorová ${ }^{2}$, Tatiana Črejová ${ }^{3}$
}

\begin{abstract}
Behind a successful company there are several factors which affect its activities and performance. These are various economic issues, production processes, capital and people- employees. The human resources of a company largely depend on how the company is able to respond to challenges of the market. Employers are recently trying to take care of their employees much more than just rewarding them with a salary. They provide them a variety of employee benefits with which they try to motivate them to better perform. The aim of the paper is to describe the system of benefits provided by companies in general. The first part of paper contains a general framework of the issue and the second part describes the current situation of providing benefits in Slovakia and abroad, specifically in the United States. The paper highlights the differences in understanding of importance of benefits in each country. The final part of the paper contains research about opinions of students of the University of Žilina about providing benefits at the workplace.
\end{abstract}

JEL Classification Numbers: J33; DOI: http://dx.doi.org/10.12955/cbup.v5.964

UDC Classification: 331,2

Keywords: work motivation, employee benefits, research, survey

\section{Introduction}

Štofková et al (2011) says that employees - human resources - are an indispensable source for success of any company. It follows that we should treat them at least with the care we treat material, finance and information resources. Therefore, the key task of human resources management is to motivate its employees to give their best performance. One part of this motivation is through rewards. Beside typical money rewards, non-monetary rewards, also known as employee benefits, gained importance in last few decades. For companies, they represent opportunity to differentiate themselves from other companies, lure new employees and retain current employees. Nowadays many companies are building their corporate identity on interesting and unique employee benefits. A typical example is the company Google.

\section{Employee Rewards}

Employee rewards are one of the main parts of a motivation program in the company. Generally, we can incorporate rewarding into three categories (Kachaňáková, 2003):

- direct money rewarding - it includes salary, bonuses, fees and commissions,

- indirect money rewarding - it includes stocks, insurance, loans, extra fee for food, clothing and more,

- non-monetary rewarding - material values - company car, phone, a variety of social benefits and services, for example. use of recreational facilities, counseling services, child care and various other.

\section{Rewarding of employees}

Employee benefits are rewards that the company provides to employees only for the fact that they are its employees. Usually, they are not tied to employee performance. Sometimes however, they depend on status of employee in the company, his merits and the time he has worked in the company.

Employee benefits can be segmented into three basic groups (Strenitzerová, 2015.):

- benefits of a social nature (corporate pensions, life insurance, business loans and guarantees for loans, child care workers (nurseries and kindergartens), etc..),

- benefits of work nature (food, discount for company products to employees, language tutor, etc..),

\footnotetext{
${ }^{1}$ Ing. Natália Stalmašeková, University of Žilina,Faculty of Operation and Economics of Transport and

Communications,Univerzitná 8215/1, 01026 Žilina, natalia.stalmasekova@ fpedas.uniza.sk

${ }^{2}$ Ing.Tatiana Genzorová, University of Žilina,Faculty of Operation and Economics of Transport and

Communications,Univerzitná 8215/1, 01026 Žilina, tatiana.genzorova@fpedas.uniza.sk

${ }^{3}$ Dr.h.c. prof. Ing. Tatiana Čorejová University of Žilina,Faculty of Operation and Economics of Transport and

Communications,Univerzitná 8215/1,01026 Žilina, tatiana.čorejova@fpedas.uniza.sk
} 
- benefits associated with the position in the company (prestigious company cars for managers, pay phone in the apartment, allowances for clothing and other expenses representation of companies, corporate apartment, etc..).

Trade unions when collective bargaining generally create pressure on providing employee benefits. If the company wants employee benefits to have a positive impact on employee motivation, their satisfaction and stability as well as good relations with trade unions, it should be interested which employee benefits employees prefer. Due to differences in the preferences of employees, companies have begun offering an optional benefit system (i.e. Cafeteria system). Employee can choose such benefits that are currently most interesting for him. In the case that his preferences will change in time, he has a possibility of choosing different benefits. (Stríček and Štofková, 2013)

The optional benefit system is convenient for the company and employee for several reasons: (Strenitzerová, 2015):

- The optional system is economical and provides the ability to better control costs and becomes more diverse and attractive;

- It leads to an increased awareness of employee benefits;

- Employee benefits are useful in the acquisition and stabilization of employees. If the company offers tailored benefits, it becomes more attractive to potential and current employees;

- The system may have a positive impact on the attitudes and behavior of employees, employees feel they are more equal partners;

- Optional systems provide companies and employees (i.e. Trade unions) the possibility of better control over the distribution of benefits, because the choice of each employee is registered and recorded.

Koubek (2007) says that the disadvantage of optional benefits system is its administrative complexity. Employees also may not always recognize their current needs, which can result in inappropriate selection of employee benefits, which can then manifest into their dissatisfaction.

\section{Current situation of issue in Slovakia}

'Employee benefits were brought to Slovakia by foreign companies which employee a significant number of people in our part of the market. For many companies, these benefits are part of their corporate culture. Slovak companies are not lagging behind and also under pressure by unions to provide employee benefits. In 2016, Slovak web journal platy.sk published on its site surveys for employee benefits where they concentrated on the most used benefits in Slovak companies during 2015. Corporate teambuilding was identified as the most common benefits provided by the employer at top of the range (26\%). Second place at $20 \%$ were both free drinks at the workplace and employee education. Education of employees includes training in their profession (meetings, workshops...), but especially the teaching of foreign languages, which is especially preferred by foreign companies. They try to educate their staff in case they need travel to other branches where they are forced to communicate with English or German-speaking colleagues. Another very common benefit is the possibility to use flexible working hours (18). Employers try to provide to employee some freedom to decide about arrival to work. Employees reported at considerable level that they can use both the company mobile phone and the PC, which is provided at work, for private purposes. Furthermore, frequent benefits are holidays, reimbursement of transport, a housing allowance or reimbursement of sporting activities. In the survey for web journal platy.sk, 32\% of respondents from a sample of 65000 people admitted that their work still has no employee benefits.

Many international companies in Slovakia offer the same benefits as in abroad branches. For example, one of the most famous employer in Žilina provides its employees financial bonuses in the form of variable pay, Christmas bonuses, and extra for overtime or additional retirement savings. Many foreign companies have acceded to promote marriages and families by giving bonuses to families with new born baby. Many companies take care of the culture of the company and its corporate social responsibility and they want to learn from their employees by using benefits, for example car factory Kia rewards blood donors. These benefits include 'eco-friendly' shopping, when on purchases friendly home appliances or use a bicycle as a means of transport provided by certain funds bearing the costs of employees. Slovak company Topvar concerned with the production of beer is giving their female employees contribution for babysitting, so they can come to work earlier. (Berecz, 2016) 


\section{Current situation in USA}

Abroad, the employers understand benefits quite differently. They realized that generous benefits are needed to attract talented employees. Based on the survey of employee satisfaction conducted by the company Glassdoor (2016) it is shown that for $60 \%$ of respondents, benefits are the main reason according to which people decide whether to take a job or not. To attract prospective talented employees, large American companies offer their employees massage chairs, private chef, and yoga classes. Large companies seek to reflect the benefits of their employees in the work carried out. For example, Airbnb, which in 2016 was declared as the best place to work, provides its employees an annual salary of $\$ 2,000$ just to travel.

\begin{tabular}{|c|c|}
\hline \multicolumn{2}{|l|}{ Table 1: Ten most desirable benefits } \\
\hline Benefits in Slovakia & Benefits in USA \\
\hline Corporate teambuilding & More flexible hours \\
\hline Free beverages & More vacation time \\
\hline Education & Work from home options \\
\hline Flexible working hours & Unlimited vacation \\
\hline Cell phones for private purpose & Student loan assistance \\
\hline Employee discounts & Tuition assistance \\
\hline Retirements savings & Paid maternity/ paternity leave \\
\hline PC for private purpose & Free gym membership \\
\hline Work from home options & Free day care services \\
\hline More vacation time & \\
\hline Source: Platy.sk and Jones (2017), respectfully. & \\
\hline
\end{tabular}

\section{Data and methodology}

The aim of this research is to find out which employee benefits do students of University of Žilina prefer. The results show the most attractive employee benefits of students-future labor. This research can point to benefits which employers can use in the future to attract good skilled graduates.

The task of the questionnaire was to find out:

- which of the following employee benefits would be most attractive for students of the University of Žilina.

- have the students ever been employed?

The research sample contains 100 students of University of Žilina. The research was performed in February 2017. For research, we had to suspect that more than half of respondents had had working experience.

We presume that young people are influenced by international companies which are doing business in Slovakia and they expect different types of benefits. Further, we expect that women desire different types of benefits than men.

\section{Results and Discussion}

The research sample consists of 100 respondents, $43 \%$ male and 57\% female. Figure 1 shows that most desired employee benefits are flexible working hours, a company car for private purpose and extra paid vacation. The use of a company car is a benefit often offered in Slovakia and employees appreciate it. Flexible working hours is a new type of employee benefit for Slovak employees which is more and more required. In the past regime, this benefit was not offered. There is only 20 paid vacation days for absolvents in Slovakia, therefore extra paid vacation is also desired. 


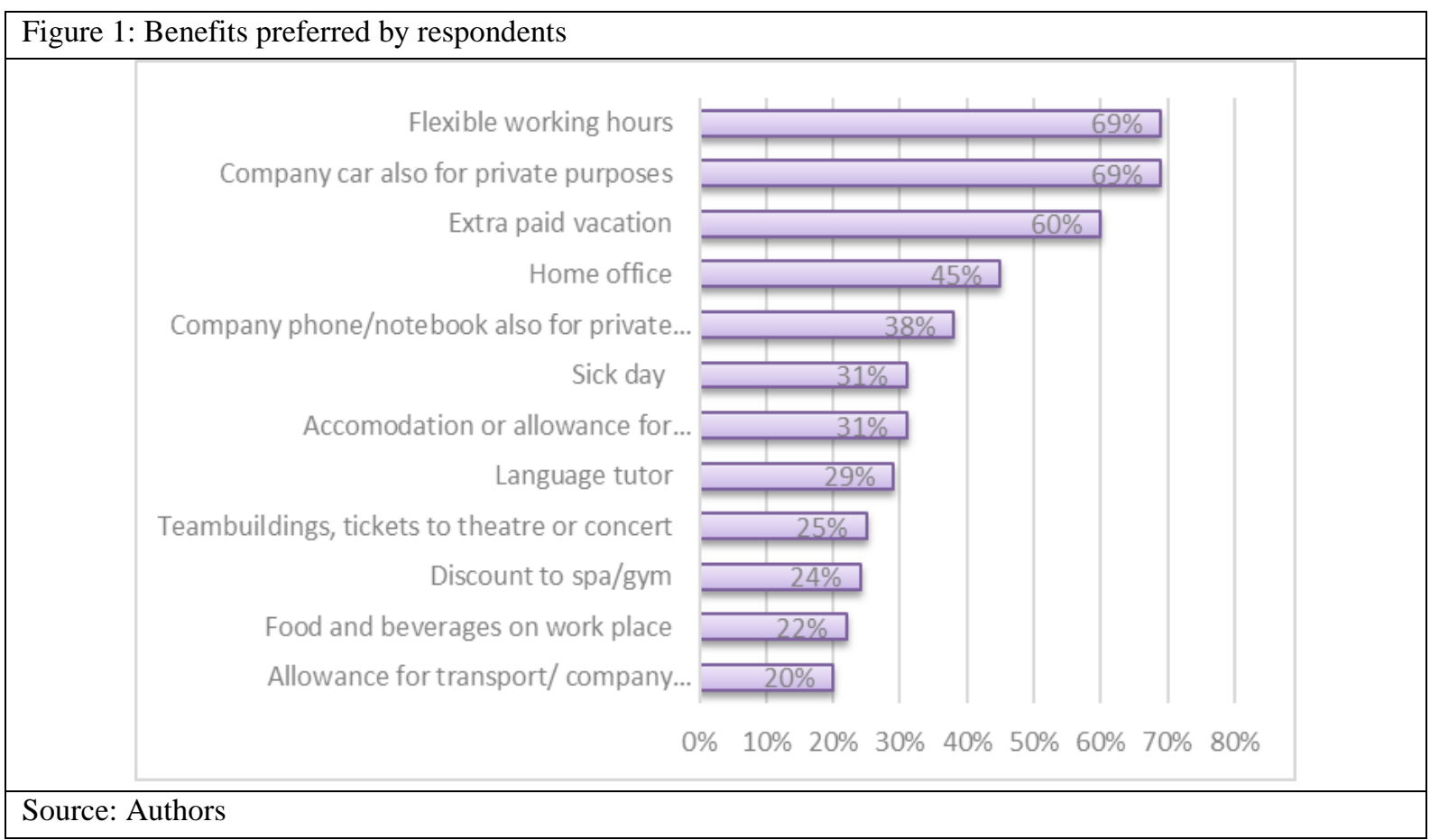

If we look at answers only from female respondents, the most desired benefits are flexible working hours, extra paid vacation and of course home office. This shows that women are concerned about time, because they have to split time between work and family more than men. On the contrary, the most desired benefits by men are a car and a phone/notebook for private purpose.

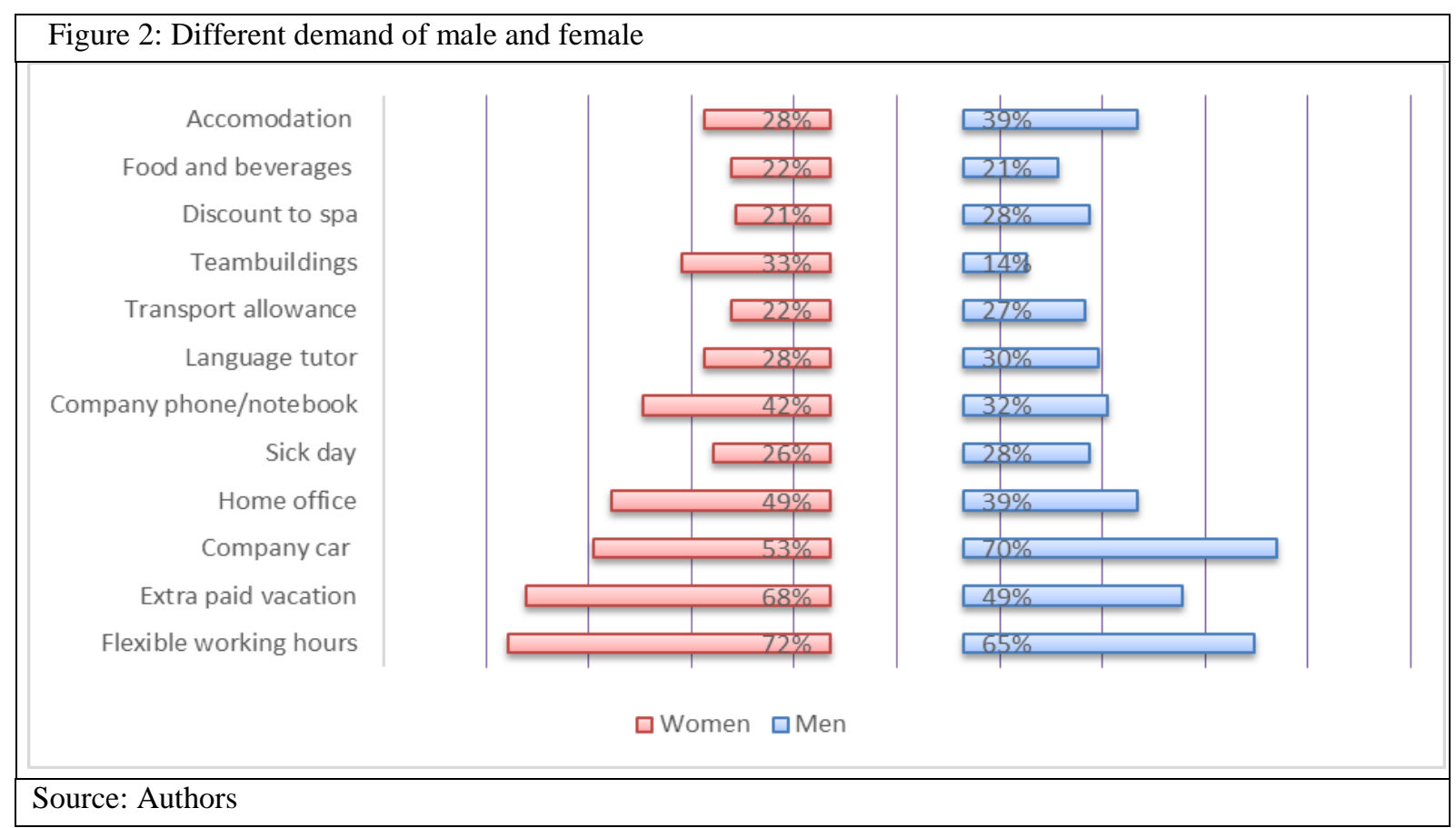

\section{Conclusion}

Employee benefits are powerful tool in the hands of companies. Benefits are a great opportunity to lure, raise and keep employees. Already Tomáš Bata emphasized the importance of keeping employees satisfied. (Štofková et al, 2015). Only satisfied employee can identify with the company and do their best work. Based on the results of the research, we recommend incorporating the Cafeteria system into the motivation program of companies if it is possible. It is convenient not only for employees but also for companies. The company could have a better control of costs as well as appearing more attractive and diverse. 


\section{Acknowledgements}

VEGA 1/0515/15 Endogenous factors of the IPR intensive industries in the regional enterprise environment in Slovak Republic

VEGA 1/0693/16 Research of innovative solutions in the context of quality management

VEGA 1/0733/15 Research of the quality management to support business competitiveness.

\section{References.}

Berecz, A. (2016). Firemné benefity na Slovenku: Aké výhody králujú na pracoviskách. Trend, Retrieved from https://www.etrend.sk/podnikanie/firemne-benefity-na-slovensku-ake-vyhody-kraluju-na-nasich-pracoviskach.html

Jones, K. (2017). The most desirable empolyee benefits. Harvard business review. Retrieved February 15, 2017 from

https://hbr.org/2017/02/the-most-desirable-employee-benefits\#comment-section

Kachaňáková, A. (2003). Riadenie l’udských zdrojov. Bratislava: SPRINT. 212 p.

Koubek, J. (2007). Řízení lidských zdrojů: základy moderní personalistiky. Praha: Management Press. 399 p.

Platy.sk (2016). V roku 2015 si zamestnanci na Slovensku polepšili, platy v Košickom kraji rástli až o 5\%. Retrieved from http://www.platy.sk/analyzy/v-roku-2015-si-zamestnanci-na-slovensku-polepsili-platy-v-kosickom-kraji-rastli-az-o-5/50215

Strenitzerová, M. (2015). Riadenie l’udských zdrojov. Bratislava: DOLIS. 217 p.

Štofková, J., Cisko, Š., Bartošová, V., Kremeňová I., Strenitzerová, M., Fl’ak, J., Jankalová, M., Madleňák, R. and Stofková, K. (2011). Manažment podniku. Žilina: EDIS. 393 p.

Štofková, J., Madleňák, R. and Repková Štofková, K. (2015). Business Management. Bratislava: DOLIS. 178 p.

Stríček, I., Štofková, K. (2013). New approaches of the management in the dynamic business environment. In: Podniková ekonomika a manažment. Retrieved from http://ke.uniza.sk/assets/casopis/PEAM32013.pdf

Glassdoor (2016). Top 20 employee benefits and perks. Retrieved from https://www.glassdoor.com/blog/top-20-employeebenefits-perks/ 